\title{
SEDIMENTS CONTAMINATION WITH ORGANIC MICROPOLLUTANTS: CURRENT STATE AND PERSPECTIVES
}

\author{
Agnieszka POPENDA ${ }^{1}$, Maria WŁODARCZYK-MAKUŁA \\ Czestochowa University of Technology, Częstochowa, Poland
}

\begin{abstract}
This study focused on the sediment contamination with some organic micropollutants based on the monitoring data together with available literature in Poland. The following persistent organic pollutants (POPs): polycyclic aromatic hydrocarbons (PAHs), polychlorinated biphenyls (PCBs) and chlorinated pesticides (CP) were characterized in sediments with respect to current legislations in force. Based on accessible data, higher PAHs, PCBs and CP concentrations were found in river sediments than in lake sediments. Especially, sediments of the Oder River and its tributary in the southern part of Poland, were highly polluted. In order to minimize the risk of the secondary pollution of surface waters, it is necessary to introduce consolidated management system with sediments proceeding. Furthermore, it is also of great importance to elaborate specific regulations concerning conditions of sediments management.
\end{abstract}

Keywords: sediments, PAHs, PCBs, chlorinated pesticides, contamination.

\section{INTRODUCTION}

In Poland sediments have been regularly sampled to control the level of concentration of some micropollutants as well as their changes in time since 1990. The extensive investigations of these compounds are carried out in the frame of the current State Programme of Environmental Monitoring in Poland

\footnotetext{
${ }^{1}$ Corresponding author: Czestochowa University of Technology, Water and Wastewater Technology, Department of Chemistry, Water and Wastewater Technology, Dabrowskiego st. 69, 42-200 Częstochowa, Poland
} 
for 2016-2020 [1]. The available monitoring data of sediments, which have been studied in this paper come from the period of 2003-2014 [2-6].

The Vistula and the Oder are two major rivers, which drain into the Baltic Sea. About $95 \%$ of the territory of Poland is within the drainage basin of these two rivers. There is most of the industry situated in the South western part of Poland - the Upper Silesian Region and Lower Silesian Region. Most of Polish lakes are located in the northern, much less industrialized part. Geochemical sediment concentration is very useful in order to estimate the quality of surface waters [7]. Current sediment investigations are used to follow the impact of anthropogenic activity on the aquatic environment [8]. The presence of contaminants in sediments is mainly caused by the afore mentioned phenomenon, including exploitation of mineral resources, their processing, industrial and agricultural production as well as the functioning of cities, water transport and trans-shipping in harbors [9]. Other sources of sediments pollution are: industrial and municipal sewage, urban runoff, pollution coming from fumes and industrial dust infiltration of leachates and sewage discharge located in river valleys, respectively [10-13]. Persistent organic pollutants are chemicals coming from man-made sources associated with production, use, and disposal of certain organic chemicals [14]. Many of these chemicals were produced commercially for pest and disease control, crop production and industrial use. Some POPs, such as: pesticides and PCBs are intentionally produced, while others such as PAHs are the by-products of industrial processes or result from the combustion of organic chemicals [15]. POPs are synthetic chemicals with the following properties: they are toxic and can have adverse effects on human health and animals. They are chemically stable and do not readily degrade in the environment [16]. They are lipophillic (have an affinity for fats) and easily soluble in fat. They accumulate and biomagnify as they move up through the food chain. They move over long distances in nature and can be found in regions far from their points of origin or use [17]. It was proved that Polish river sediments and several lakes are heavily polluted with (POPs). Investigations into sediments are of prime importance with respect to the Frame Water Directive that obligates EU countries to establish national monitoring programmers of surface waters in order to deliver compatible information of both the ecological state and chemical waters in each catchment area as well it is important to classify the above mentioned waters [18].

In the paper the short brief of contamination with some persistent organic pollutants such as: polycyclic aromatic hydrocarbons (PAHs), polychlorinated biphenyls (PCBs) and chlorinated pesticides (CP) in river and lake sediments was studied. Therefore, this paper deals with the state of pollution of sediments in Poland indicating the potential risk to aquatic environment coming from 
polluted sediments. Due to the lack of specific regulations concerning the assessment the state of water sediment as well as the way of sediments carrying the proposal of polluted sediment management is also included in the paper.

\section{LEGISLATIONS CONSIDERING SEDIMENTS}

The forms and manner to monitor surface water and groundwater bodies are taken into consideration with respect to monitoring the Regulation of the Minister of the Environment of 13 May 2011 [19] as well as Regulation of the Minister of the Environment concerning the list of priority substances in water politics [20]. The monitoring description is submitted to the European Commission as a part of reporting obligations regarding the implementation of the Water Framework Directive 2006/60/EC [18] as well as Water Framework Directive 2008/105/EC [21]. Other important legislation refers to the Stockholm Convention on Persistent Organic Pollutants [22].

Up till the end of 2012 sediments were treated as hazardous materials (code 17 $0505^{*}$ ) if the concentration one of the listed substances in Legal Polish regulation of Ministry of Environment that defines types and concentrations of substances indicating that dredging spoil originating from excavation of water harbour (in order to keep infrastructure assuring access to harbours) as well as from excavation of water reservoirs, ponds, natural streams, canals and ditches (in order to keep water control) exceeds the permissible values [23]. According to the aforementioned regulation the following contaminants are listed:

- seven PAHs: benzo(a)anthracene, benzo(b)fluoranthene, benzo(k)fluoranthene, benzo(ghi)perylene, benzo(a)pyrene, dibenzo(a,h)anthracene and indeno (1,2,3- c,d) pyrene,

- seven PCBs: PCB28, PCB52, PCB101, PCB118, PCB138, PCB153 and PCB180.

The way of managing of dredging spoil is also determined on the basis of legislation of Environmental Ministry that defines standards of quality of soil and sediments originating from the bottom of surface flowing or stagnant water reservoirs [24]. The following contaminants are listed:

- sum of the following PAHs: naphthalene, phenanthrene, anthracene, fluoranthene, chrysene, benzo(a)anthracene, benzo(a)fluoranthene, benzo(ghi)perylene, benzo(a)pyrene,

- sum of congeners PCBs: 28,52,101,118,138,153 and 180,

- and additionally the following chlorinated pesticides: DDT, Aldrin, Dieldrin, Endrin and isomers of $\mathrm{HCH}(\alpha \mathrm{HCH}, \beta \mathrm{HCH}$ and $\gamma \mathrm{HCH})$.

The above mentioned legislation includes three groups of soils. Group A includes real properties being part of areas of protection basing on the 
regulations of the Water Act, areas of protection basing on regulations of nature protection; if the current level of contamination of soils does not make a hazard for humans health or environment- for those areas concentrations keep standards resulting from the state. Group B includes agricultural soils excluding soils under ponds and ditches, forests and bush areas, barrens as well as built-up and urban areas excluding industrial areas, fossils and communications areas. Group $\mathrm{C}$ includes industrial areas, fossils and communications areas.

\section{POLYCYCLIC AROMATIC HYDROCARBONS (PAHS) IN SEDIMENTS}

PAHs are regarded as persistent organic pollutants (POPs) resulting often from anthropogenic processes [25]. Fuel distribution and combustion and coal tar emissions are considered as the main sources of PAHs in the environment [13]. The environmental level of PAHs pollution depends on the distance of these compounds from emission sources. The highest PAHs concentration is found in the air of highly industrial and communication pathways in agglomerations [10]. Air pollution, fuel distribution and combustion and coal tar emissions are regarded as the main sources of PAHs in sediments [26]. In sediments hydrocarbons occur together with municipal, industrial wastewater and surface run-off as well as a result of the sedimentation of solid particles coming from the air [27]. In the water they are present in much lower concentration due to their low water solubility (up to $0.001 \mathrm{mg} / \mathrm{l}$ ) [27]. Simultaneously PAHs accumulates in sediments with concentrations of $1000 \mathrm{mg} / \mathrm{kg}$ [10]. Concentration of PAHs in sediments and soils varies from $0.005 \mathrm{mg} / \mathrm{kg}$ on areas situated far from industry and not use in agriculture up to several thousand of $\mathrm{mg} / \mathrm{kg}$ on refineries or cocking plants as well as rivers receiving wastewater originating from the aforementioned plants $[28,29]$. The concentration in sandy uncontaminated sediments is very low ranging $0.1 \mathrm{mg} / \mathrm{kg}$, whereas sediments rich in organic matter, e.g. lake sediments have a concentration of PAHs of 1 $\mathrm{mg} / \mathrm{kg}$ [10]. The research on pollution of the bottom of rivers and lakes, lake canals and reservoirs is carried out within the framework of the subsystem of the monitoring of surface waters - [28]. During geochemical investigations into sediments, grain fraction of $<0.2 \mathrm{~mm}$ is used [7,27]. The following $19 \mathrm{PAHs}$ were determined: naphtalene, acenaphtylene, acenaphtene, fluorene, phenanthrene, anthracene, fluoranthene, pyrene, benzo(a)anthracene, chrysene, benzo(b)fluoranthene, benzo(k)fluoranthene, benzo(a)fluoranthene, benzo(a)pyrene, benzo(e)pyrene, perylene, dibenzo(ah)anthracene, indeno(1,2,3-cd)pyrene and benzo(ghi)perylene. According to monitoring data from the years 2003-2005 it was found that the Oder River sediments are 
heavily contaminated with PAHs with the highest concentration of $49 \mathrm{mg} / \mathrm{kg}$ sum of 15 PAHs listed by Environmental Protection Agency (EPA) (except naphthalene) [28]. Poland is divided into seven Regional Water Management (RWM) zones of: Gdańsk (Gd), Gliwice (Gl), Cracow (Kr), Poznań (Pz), Szczecin (Sz), Warsaw (Wa), and Wrocław (Wr). According to available monitoring data from the years 2009-2011 sediments taken from the rivers were highly loaded with PAHs (Table 1) [2-4].

Table 1. Ranges of PAHs concentration in sediments originating from location points of the rivers treated as contaminated $\mu \mathrm{g} / \mathrm{kg}[2-4]$.

\begin{tabular}{|l|l|l|l|}
\hline PAH & 2009 & 2010 & 2011 \\
\hline Acenaphtylene & $20-668$ & n.d & $9-418$ \\
\hline Acenaphtene & $7-709$ & n.d & $8-409$ \\
\hline Fluorene & $12-1048$ & $55-2230$ & $13-901$ \\
\hline Phenanthrene & $311-6366$ & $488-15695$ & $249-4973$ \\
\hline Anthracene & $93-1526$ & $123-6566$ & $65-2189$ \\
\hline Fluoranthene & $1465-6576$ & $1380-26884$ & $812-8459$ \\
\hline Pyrene & $1260-6240$ & $1149-19057$ & $671-6100$ \\
\hline Benzo(a)anthracene & $780-3581$ & $725-9452$ & $389-3057$ \\
\hline Chrysene & $690-3382$ & $690-8036$ & $339-2458$ \\
\hline Benzo(b)fluoranthene & $753-4396$ & $882-8430$ & $383-2628$ \\
\hline Benzo(k)fluoranthene & $423-1889$ & $451-4231$ & $201-1543$ \\
\hline Benzo(a)pyrene & $677-3926$ & $895-9523$ & $378-3897$ \\
\hline Dibenzo(ah)anthracene & $107-689$ & $137-1014$ & $286-2387$ \\
\hline Indeno(1,2,3-cd)pyrene & $885-2909$ & $748-6151$ & $63-542$ \\
\hline Benzo(ghi)perylene & $438-2663$ & $672-6305$ & $277-2419$ \\
\hline
\end{tabular}

n.d - no data

In 2009 the total concentration of 15 PAHs ranged the value of $43.5 \mu \mathrm{g} / \mathrm{kg}$ in sediments originating from the Bystrzyca River neighbourhood of Wrocław [2]. Sediments coming from the Oder River should be pointed out as the most contaminated ones. The concentration of carcinogenic compounds exceeded in many samples the permissible values, including benzo(a)pyrene with the value of $4 \mathrm{mg} / \mathrm{kg}$. In 2010 the highest concentration of sediments was still present in the Oder River, mainly in sediments of Chałupki with the sum of 13 hydrocarbons equal to $123.6 \mathrm{mg} / \mathrm{kg}$ [3]. However, the analysis in the further years indicates that the afore mentioned concentration occurred periodically [5]. The determined PAHs concentration in sediments in 2011 were similar to those found in 2009. The highest total concentration of 15 PAHs was equal to 39.5 $\mathrm{mg} / \mathrm{kg}$ and was found in sediments of the Oder River in Chałupki. In 2012 the decrease of PAHs concentration was observed [5]. It is estimated that the highest concentration did not exceed the value of $32 \mathrm{mg} / \mathrm{kg}$. $\mathrm{B}(\mathrm{a}) \mathrm{P}$ 
concentration was high, exceeding the permissible value in some location points on the Oder River. The total concentration of PAHs equal to $31 \mathrm{mg} / \mathrm{kg}$ was found in sediments coming from Maszówek Canal.

According to the monitoring data originating from 2014 the concentration of persistent organic pollutants was determined in sediments coming from 25 measurement points located on the Polish rivers [6]. 7 points were located on the Oder River, whereas on the Vistula River 6 measurement points; the remaining points were located on tributaries of the mentioned rivers. The total concentration of 19 compounds ranged the value of $65 \mathrm{mg} / \mathrm{kg}$. The most contaminated were sediments of the Oder River in Chałupki and Widuchowa, the values varied from $56 \mathrm{mg} / \mathrm{kg}$ to $65 \mathrm{mg} / \mathrm{kg}$. In another location points on the Oder River the PAHs concentration was two times lower.

In general, the sediments coming from the Vistula River were much lower polluted with hydrocarbons. The total concentration of PAHs in sediments varied from $0.3 \mathrm{mg} / \mathrm{kg}$ to $6 \mathrm{mg} / \mathrm{kg}$. In the remaining location points the PAHs concentration was in the range of $0.5-20 \mathrm{mg} / \mathrm{kg}$, respectively.

The monitoring of POPs pollutants includes also lake sediments. The highest PAHs concentration of the total 15 PAHs of $10.573 \mathrm{mg} / \mathrm{kg}$ was found in the Białe Włocławskie Lake (RWM Wa) [30]. Monitoring data from the years 2009-2011 indicate that sediments taken from the lakes were highly contaminated with PAHs as well (Table 2) [2-4]. In 2009 the highest total concentration of $15 \mathrm{PAHs}$ ranged up to $50 \mathrm{mg} / \mathrm{kg}$ with carcinogenic hydrocarbons comprises of $61 \%$ was found in sediments taken from the Człuchowskie Lake. In 2010 the maximal total concentration of 11 PAHs in lake sediments were two times lower than in 2009 and did not exceed the value of $20 \mathrm{mg} / \mathrm{kg}$. Lake sediments of wielkopolskie and zachodniopomorskie voivioships were the most polluted with PAHs. The decrease trend was not found in the further period as the total concentration of PAHs in sediments ranged the value of $34 \mathrm{mg} / \mathrm{kg}$ in 2011 [4]. In 2012 the PAHs concentration ranged the value of $24 \mathrm{mg} / \mathrm{kg}$ [5]. The high $\mathrm{B}(\mathrm{a}) \mathrm{P}$ concentration was also found in Łąckie, Łęgowskie and Karczemne lake sediments, respectively.

Table 2. Ranges of PAHs concentration in sediments originating from the location points of the lakes treated as contaminated $\mu \mathrm{g} / \mathrm{kg}[2-4]$

\begin{tabular}{|l|l|l|l|}
\hline PAH & 2009 & 2010 & 2011 \\
\hline Acenaphtylene & $23-202$ & n.d & $24-228$ \\
\hline Acenaphtene & $30-175$ & n.d & $25-207$ \\
\hline Fluorene & $46-194$ & $26-206$ & $47-470$ \\
\hline Phenanthrene & $282-2865$ & $219-1154$ & $336-3310$ \\
\hline Anthracene & $66-666$ & $68-491$ & $69-1007$ \\
\hline Fluoranthene & $1305-8281$ & $1113-3696$ & $1105-9050$ \\
\hline
\end{tabular}


SEDIMENTS CONTAMINATION WITH ORGANIC MICROPOLLUTANTS: CURRENT 95 STATE AND PERSPECTIVES

\begin{tabular}{|l|l|l|l|}
\hline Pyrene & $642-6543$ & $903-2815$ & $858-7411$ \\
\hline Benzo(a)anthracene & $351-3434$ & $404-1498$ & $421-3561$ \\
\hline Chrysene & $388-4047$ & $476-1647$ & $476-4079$ \\
\hline Benzo(b)fluoranthene & $817-6378$ & $727-2585$ & $608-6015$ \\
\hline Benzo(k)fluoranthene & $411-2679$ & n.d & $315-2980$ \\
\hline Benzo(a)pyrene & $459-3862$ & $461-1824$ & $457-4262$ \\
\hline Dibenzo(ah)anthracene & $145-892$ & n.d & $96-969$ \\
\hline Indeno(1,2,3-cd)pyrene & $804-2540$ & $630-2257$ & $518-4743$ \\
\hline Benzo(ghi)perylene & $757-4264$ & $624-2239$ & $543-4630$ \\
\hline
\end{tabular}

n.d -no data

In 2014 lakes sediments were analyzed in 24 measurement points. The range of the total PAHs concentration varied from $3.3 \mathrm{mg} / \mathrm{kg}$ to $20.7 \mathrm{mg} / \mathrm{kg}$ and was similar to the PAHs concentration in the river sediments. The PAHs concentration above $19 \mathrm{mg} / \mathrm{kg}$ was found in the sediments originating from the Bysławskie Lake (kujawsko-pomorskie voivodedship) and the Garbicz lake (lubuskie voivodedship), respectively [6].

The investigations of PAHs content in Polish sediments were also conducted by other researchers [29-32]. Within the framework of the International Oder Project the organic pollution level in the Oder river sediments was studied [29]. The results of multi-annual investigations indicate that the main problem, particularly in the upper course of the Oder River, is caused by polycyclic aromatic hydrocarbons present in sediments with the concentrations in the range of $30-60 \mathrm{mg} / \mathrm{kg}$. The pollution is influenced by the presence of highly urbanized regions, and in the north of Czech Republic as well as by the large heat- and power generating plants, with the biggest one closed to Opole, which are located in the southern part of the Oder River catchment area. Kostecki at el. investigated the total concentration of 16 PAHs in sediments of strong polluted dam-reservoir Dzierżno-Duże (Western Part of Upper Silesian Region in South of Poland). He concluded that the PAHs concentration in sediments has not grown since 1979 and was about $30 \mathrm{mg} / \mathrm{kg}$ near the Klodnica estuary and it gradually decreases [31]. In the distance of $700 \mathrm{~m}$ from the first part of the water reservoir PAHs concentration was lower of the $80 \%$ of the initial contents. The investigations into PAH content in sediments coming from Gliwicki Canal were carried out by Kostecki [32]. The concentration was various depending to the distance from the Gliwice Canal as well as development of the buildings. The highest total concentration of PAHs ranging $8 \mathrm{mg} / \mathrm{kg}$ was determined in the initial section of the Canal then, the PAHs concentration varied with the decreasing tendency with the distance. The author concluded that sediments originating from Gliwicki Canal should be treated as highly contaminated [32]. Tomza at el. investigated contamination with PAHs 
sediments of two renovated small ponds situated in village park Pawłowice on the border of town Wrocław [33]. Concentrations of PAH in bottom sediments were typical for water bodies in agricultural catchments, and ranged the following values: benzo(b)fluorathene $-0.60 \mathrm{mg} / \mathrm{kg}$, benzo(k)fluorathene -0.26 $\mathrm{mg} / \mathrm{kg}$, benzo(a)pyrene - $0.39 \mathrm{mg} / \mathrm{kg}$, benzo(ghi)perylene $-0.46 \mathrm{mg} / \mathrm{kg}$, and indeno $(1,2,3-\mathrm{c}, \mathrm{d})$ pyrene $-0.89 \mathrm{mg} / \mathrm{kg}$, respectively.

\section{POLYCHLORINATED BIPHENYLS (PCBS) IN SEDIMENTS}

Another group of POPs is polychlorinated biphenyls (PCBs). Prior to the 1979 ban, PCBs entered the environment during their manufacture and use in the United States. PCBs were also commonly used as stabilizing additives in the manufacture of flexible PVC coatings for electrical wiring and electronic components to enhance the heat and fire resistance of the PVC [34]. Today PCBs can still be released into the environment from poorly maintained hazardous waste sites that contain PCBs; illegal or improper dumping of PCB wastes; leaks or releases from electrical transformers containing PCBs; and disposal of PCB-containing consumer products into municipal or other landfills not designed to handle hazardous waste [10]. PCBs may also be released into the environment by the burning of some wastes in municipal and industrial incinerators. Once in the environment, PCBs do not readily break down and therefore may remain for long periods of time cycling between air, water, and soil. In general, the lighter the form of $\mathrm{PCB}$, the further it can be transported from the source of contamination. In water, a small amount of PCBs may remain dissolved, but most are attached to organic particles and sediments. PCBs accumulate in fish and marine mammals, reaching levels that may be many thousands of times higher than in the water [30]. PCBs have never been produced in Poland on a technique scale, the exception was found for Nitrogen Plant in Tarnów. In the 70-ies, there were some attempts in half-technique scale. However, the significant import of electro technical devices containing PCBs as well oils for them was carried out in the above mentioned plant [35]. At present, sediments may contain concentrations of PCBs up to several hundred of $\mu \mathrm{g} / \mathrm{kg}$ [36]. The investigations of PCBs are carried out in the frame of State Programme of Environmental Monitoring in Poland [1]. The monitoring data from the period 2003-2005 show high pollution of the river sediments with PCBs in the Warta River with the maximal concentration of $29.8 \mathrm{mg} / \mathrm{kg}$ [30]. High concentrations of PCBs were found in the river sediments of southern part of Poland [30]. Available monitoring data from the years 2009-2012 confirm the presence of PCBs in Polish river and lake sediments Table 3 [2-5]. 
Table 3. Ranges of concentrations of PCB in sediments coming from the location points on rivers and lakes treated as contaminated, $\mu \mathrm{g} / \mathrm{kg}[2-5]$

\begin{tabular}{|l|l|l|l|l|}
\hline PCB & 2009 & 2010 & 2011 & 2012 \\
\hline $\begin{array}{l}\text { PCB - sum of seven } \\
\text { congeners }\end{array}$ & $0.35-180.6$ & n.d & to 356.6 & $4.2-44.1$ \\
\hline
\end{tabular}

n.d - no data

The total sum of PCBs in river sediments varied within the period of 2009-2012 ranging the highest value of $356.6 \mu \mathrm{g} / \mathrm{kg}$ in 2011 [2-5]. According to data originating from 2014 the concentration of six PCBs (PCB 28, PCB 52, PCB 101, PCB 138, PCB 153, PCB 180) in the river sediments was high and ranged the value of $55 \mu \mathrm{g} / \mathrm{kg}$ in the sediments coming from Łososina River in Witowice Górne [6]. In sediments coming from the Oder River the total PCBs concentration did not exceed the value of $12 \mu \mathrm{g} / \mathrm{kg}$, whereas in the Vistula River did not exceed the value of $4.2 \mu \mathrm{g} / \mathrm{kg}$, respectively. Lake sediments were lower contaminated with PCBs and did not exceed the value of $10 \mu \mathrm{g} / \mathrm{kg}$, whereas sediments from the river canals ranged the value of $2.6 \mu \mathrm{g} / \mathrm{kg}$ [6]. In lake sediments the sum of the determined PCBs ranged $26 \mu \mathrm{g} / \mathrm{kg}$, however in most location points did not exceed the value of $13 \mu \mathrm{g} / \mathrm{kg}$ [6]. In the study carried out by Bojakowska in sediments of Włocławek reservoir (Poland) PCBs up to $28.53 \mu \mathrm{g} / \mathrm{kg}$ were found [37]. Within the framework of the International Oder Project the PCBs level in the Oder River sediments was studied [29]. The highest determined value $77 \mu \mathrm{g} / \mathrm{kg}$ was found in the region where pulp and paper industry is situated. In the sediments of Baltic Sea ranges of concentration of PCBs varies from 10 to $1380 \mu \mathrm{g} / \mathrm{kg}$ [38]. The investigations into selected PCB congeners in sediments originating from the water reservoir in Sulejów as well as from Pilica River was conducted by Urbaniak and co-authors [39]. In Table 4 the ranges of determined PCBs concentration are included [39].

Table 4. Ranges of determined PCBs concentration in sediments of water reservoirs in Sulejów and Pilica River [39]

\begin{tabular}{|l|l|l|l|l|l|}
\hline $\begin{array}{l}\text { non-orto } \\
\text { Coplanar } \\
\text { congeners }\end{array}$ & $\begin{array}{l}\text { Range of } \\
\text { concentratio } \\
\text { n ng/kg d.m }\end{array}$ & $\begin{array}{l}\text { mono- } \\
\text { orto } \\
\text { congeners }\end{array}$ & $\begin{array}{l}\text { Range of } \\
\text { concentrati } \\
\text { on ng/kg } \\
\text { d.m }\end{array}$ & $\begin{array}{l}\text { mono-orto } \\
\text { congeners }\end{array}$ & $\begin{array}{l}\text { Range of } \\
\text { concentration } \\
\text { ng/kg d.m }\end{array}$ \\
\hline PCB-77 & $0.01-0.27$ & PCB-105 & $0.72-5.83$ & PCB-156 & $0.04-1.60$ \\
\hline PCB-81 & $0.53-5.88$ & PCB-114 & $0.10-0.72$ & PCB-157 & $0.02-0.38$ \\
\hline PCB-126 & $0.02-0.17$ & PCB-118 & $1.08-9.46$ & PCB-167 & $0.07-0.65$ \\
\hline PCB- 169 & to 0.09 & PCB- 123 & to 1.90 & PCB- 189 & $0.04-0.16$ \\
\hline
\end{tabular}

The total concentration of coplanar biphenyls was in the range of $0.58-6.30$ $\mathrm{ng} / \mathrm{kg}$, whereas for other biphenyls the concentration ranged to the value of 20 $\mathrm{ng} / \mathrm{kg}$. Considering toxicity co-efficient, according to World Human 
Organization (WHO), the total concentration of PCBs was in the range of 0.11$0.96 \mathrm{ng} \mathrm{TEQ} / \mathrm{kg}$. The proper choice of taking the samples allowed to analyze changes in the concentration of studied compounds according to the flow rate. It was observed that the average percentage of decrease of the total PCBs was equal to $29 \%$ (45\% for coplanars and $25 \%$ for mono-orto PCB) [39].

\section{CHLORINATED PESTICIDES (CP) IN SEDIMENTS}

At present, concentration of individual of another group of POPs including chlorinated pesticides (CP) (e.g. HCH and DDT) varies from below the detection limit to several hundred $\mathrm{mg} / \mathrm{kg}$ under extreme conditions [37]. The most common group of pesticides- DDT was released into the air and on soil or water when it was sprayed on crops and forests to control mosquito and other insects in large amounts. Although the use of DDT is no longer permitted in the U.S., it may be released into the atmosphere in other countries (for example, Mexico and China) where it is still manufactured and used. Also, DDT, DDE and DDD may enter the atmosphere during evaporation from contaminated water and soil. DDT, DDE, and DDD in the air may then be deposited on land or surface waters [38]. DDT, DDE, and DDD last in the soil for a very long time, potentially for hundreds of years. Some soil particles with attached DDT, DDE, or DDD may get into rivers and lakes through surface runoff.

In surface waters, DDT will bind to particles in the water, settle, and be deposited in the sediment. DDT is taken up by small organisms and fish in the water [6]. In these animals, its concentration can reach levels many thousands of times higher than in water [29]. DDT in soil can also be absorbed by some plants and by the animals or people who eat those crops. Most agricultural chemicals were not used directly in aquatic environments, but entered them through run-off from land. The Stockholm Convention (ratified in 2001) banned the use of several organochlorine pesticides, including aldrin, chlordane, DDT, dieldrin, endrin, heptachlor, mirex, and toxaphene [40]. Though organochlorines continue to be used as agricultural pesticides and for mosquito control (e.g., for malaria) in developing countries. Chlorinated pesticides enter into the water environment together with municipal wastewater and wastewater originating from farms e.g. lindane is a compound of pharmaceutics and personal care products.

In Poland mainly DDT, $\mathrm{HCH}$ were produced [37]. In production of pesticides products Dieldrin (till 1975), hexachlorobenzene, heptachlor (only in 1966), endrin (till 1972) and aldrin (till 1975) were applied. Finished pesticides containing aldrin, dieldrin and endrin were imported and have been in turnover as pesticides since 1978. The longest applied preparation was Lasochrom that 
contained DDT. The major local source of releasing of chlorinated pesticides into environment is leachates from the dumping sites on which industrial wastes coming from the production of these compounds are placed. Usually in sediment concentration of pesticides does not exceed $1 \mathrm{mg} / \mathrm{kg}$ [30]. Neighborhood of urban-industrial centers resulted in higher concentrations of chlorinated pesticides mainly found in river sediments. The most frequently detected pesticides were isomer $\mathrm{HCH}$ (Lindane) with the maximal contents of 83.250 $\mu \mathrm{g} / \mathrm{kg}$ in RWM Gliwice [30]. The presence of DDT and its metabolites was detected in almost all analyzed sediments with the maximal concentration of 18 $\mu \mathrm{g} / \mathrm{kg}$ in RWM Poznań (Przemsza and Vistula River) [30]. They were also found in Warta River, the largest tributary of Oder River. The average concentrations of heptachlor, heptachlor epoxide in sediments were of 0.45 $\mu \mathrm{g} / \mathrm{kg}$, Aldrin, Endrin Dieldrin was found in average concentration of 0.15 $\mu \mathrm{g} / \mathrm{kg}$. Generally lower concentrations were found in lakes as compared to river sediments. It is due to the fact that the most of Polish lakes are located in the northern that is much less industrialized part of Poland. Within the framework of the International Oder Project the pesticides level in the Oder River sediments was studied [29]. The highest determined value of pesticides in sediments $33 \mu \mathrm{g} / \mathrm{kg}$ found in the region of Szczecin and the Szczecin Lagoon indicates that pollution can be caused by the waste disposal sites located in this region. Another causative factor may be the high total inflow of water from the Oder River to the Pomeranian Bay, which aids the accumulation of pesticides in sediments. Selected organochlorine pesticides have been determined in precipitation samples collected at ten sites in the Gdańsk region (northern Poland) over a period of three years (1998-2000) [41]. The following compounds were detected the most frequently: $\alpha-\mathrm{HCH}$ (1-12 ng/l), DDT 1-10 ng/L, DDE 1-6 ng/l) DDD (1-6 ng/L). The concentrations observed were also affected by the inflow of polluted air masses from the southwest. The total pesticide concentration in the precipitation samples was strongly related to the abundance of green areas in the vicinity of the sampling sites. In sediments of Włocławek reservoir (Poland) DDT occurred in the range of $0.7-24.0 \mu \mathrm{g} / \mathrm{kg}$ [37]. In studies in sediments coming from small lakes and canals supplied by rainwater in the area of Opole in tested samples high concentrations of DDT $(28.3 \mu \mathrm{g} \mathrm{g} / \mathrm{kg}$ and $25.5 \mu \mathrm{g} \mathrm{g} / \mathrm{kg})$ and $\mathrm{g}-\mathrm{HCH}$ compounds $(0.7 \mu \mathrm{g} / \mathrm{kg}, 2.9 \mu \mathrm{g} / \mathrm{kg}$ and $1.8 \mu \mathrm{g} / \mathrm{kg}$ ) were found. The authors compared the obtained data to the regulation considering the application as fertilizers on agricultural soils and concluded that due to the high concentration of DDT and g-HCH compounds this is not possible [42]. In another study carried out in sediments of the Baltic Sea the concentration of the most common pesticide- DDT varied from 1 to 118 $\mu \mathrm{g} / \mathrm{kg}$ achieving the maximum value in Botnicka Bay [43]. Available 
monitoring data from the period 2009-2012 confirmed the presence of organic pesticides such as: $\mathrm{HCH}$, DDT metabolites (DDD and DDE) in Polish river and lake sediments (Table 5) [2-5].

Table 5. Ranges of concentrations of selected organic pesticides in sediments coming from the location points on rivers and lakes treated as contaminated, $\mu \mathrm{g} / \mathrm{kg}$ [2-5].

\begin{tabular}{|c|c|c|c|c|}
\hline Pesticide & 2009 & 2010 & 2011 & 2012 \\
\hline a-HCH & $0.25-15.4$ & $8.7-51.0$ & $1.5-22.5$ & \multirow{4}{*}{$\begin{array}{l}\text { up to } 11.8 \\
\text { Sum of isomers } \\
\mathrm{HCH}\end{array}$} \\
\hline b-HCH & $0.25-189.6$ & n.d & to 4.9 & \\
\hline g-HCH & $0.25-4.6$ & $2.1-33.0$ & to 3.2 & \\
\hline d-HCH & $0.25-28.0$ & n.d & to 7.3 & \\
\hline DDE & $0.3-248.3$ & $0.8-51.0$ & $0.2-150.0$ & \multirow{3}{*}{$\begin{array}{l}0.9-157.6 \\
\text { Sum of } \\
\text { metabolites of } \\
\text { DDT }\end{array}$} \\
\hline DDD & $0.3-913.0$ & $0.3-137.0$ & $0.3-450.0$ & \\
\hline DDT & $0.25-2780.0$ & $0.25-349.0$ & to 2145.0 & \\
\hline
\end{tabular}

n.d -no data

Among determined $\mathrm{HCH}$ isomers, the highest concentration ranging $190 \mu \mathrm{g} / \mathrm{kg}$ was found in the sediments of the Vistula River in Grabie. The metabolites of DDT were determined in most samples, although the production of this compound is banned from several dozen years. In 2009 the total concentration ranged $4 \mathrm{mg} / \mathrm{kg}$, in the further years the contents fluctuations were found; in $2011 \mathrm{did}$ not exceed the value of $3 \mathrm{mg} / \mathrm{kg}$ [2-5]. Sediments originating from canals were much lower loaded with pesticides and did not exceed the value of $16 \mu \mathrm{g} / \mathrm{kg}$. According to data originating from 2014 the investigations of pesticide compounds indicate that although some of them are not currently apply they are still present in the sediments [6]. For example, the concentration of DDT and its isomers ranged the value of $362 \mu \mathrm{g} / \mathrm{kg}$. The most loaded with DDT were sediments taken from the Vistula River in Kopanka. The similar concentration of DDT $(310 \mu \mathrm{g} / \mathrm{kg})$ was found in sediments from the Vistula River originating from Tyniec. Compare to PAHs content the DDT concentrations were lower in the Oder River sediments then in the Vistula River and did not exceed the value of $11 \mu \mathrm{g} / \mathrm{kg}$. The highest total $\mathrm{HCH}$ concentration with isomers including lindane ranged the value of $161 \mu \mathrm{g} / \mathrm{kg}$ and occurred in sediments of the Przemsza River in Jeleń. In the remaining sediments originating from Polish rivers the concentration did not exceed the value of 25 $\mu \mathrm{g} / \mathrm{kg}$. The lakes sediments were lower loaded with the $\mathrm{HCH}$, as in most cases their concentrations were below the detection limit (from $2 \mu \mathrm{g} / \mathrm{kg}$ to $7 \mu \mathrm{g} / \mathrm{kg}$ ) [2-5]. The concentration of HCB in sediments were the lowest among determined pesticides and in river sediments did not exceed the value of 10 $\mu \mathrm{g} / \mathrm{kg}$, whereas in lake sediments the value of $0.7 \mu \mathrm{g} / \mathrm{kg}$, respectively. In the studies carried out by Tomza-Marciniak at el. the authors exanimated the degree 
of DDT and its metabolite bioaccumulation (biota sediment accumulation factor, BSAF and biota-water accumulation factor, BCF) in certain aquatic biota collected from the lower Oder River [31]. The authors expected low concentrations of the compound due to the fact that of 30-year-old ban on DDT use in Poland. DDT and its metabolites were detected in the range of 11.478 $2.292 \mu \mathrm{g} / \mathrm{kg}$, respectively. In water and sediment samples from several sites, the DDT/DDE ratio was higher than 1 , indicating fresh input of DDT in the studied area or inhibition of its breakdown.

\section{CRITICAL REVIEW AND OUTLOOK}

The only possible comparison of obtained results can be carried out with respect to data originating from the State Programme of Environmental Monitoring, as they include the same sampling points, reference methods of the sample determination according to proper legislation. The obtained data indicate that contaminants are still present in sediments and it is not always possible to observe the decreasing trends in their concentration. The fluctuations in the concentration of pollutants are often found, that indicates the incidental anthropogenic sources being difficult to eliminate. The aim of studies carried out in the frame of National Environmental Monitoring is to inform of the current chemical state of the river and lake sediments. The programme is mainly concentrated on the control of harmful, among others, organic substances being cumulated in sediments. Furthermore, it allows to continue the monitoring of the sediment quality in the rivers and lakes together with biological estimation and other parameters influencing the release of sorbed compounds to the waters. That allows to fulfill obligations included in: Water Framework Directive 2006/60/EC [18], Water Framework Directive 2008/105/EC [21] and legislation [19]. Monitoring of the quality of river and lakes sediments and their analysis allows not only the possibility of the integrate information for current estimation of the water state but in the further step will determine the achievements of Community environmental purposes included in the Water Framework Directive. That will enable to: e.g. limit of inflow of contaminants to groundwaters and as a consequence achievement of the good level of the water quality. Another advantage will be the gradual reduction of contamination of harmful substances as well as implementations of the activities to reverse undesirable trends of contaminants formed during human activity. It should also be pointed out that increasing interest of sediment pollutants appears in the control of sediment quality of the river canals and dam reservoirs that is carried out carried out in the frame of the current State Programme of Environmental Monitoring since 2010. Furthermore, it seems to 
reasonable to extend both the range of monitoring investigations and sampling points of the rivers and their tributaries and other reservoirs that are sources of water supply for drinking purposes. It is difficult or even impossible to compare data of sediment contamination carried out by other authors due to various locations of sampling points and applied analytical methods. However, there is still lack of one uniform method of the estimation of the level of pollution of sediments as well as methods of handle and sediments management in Poland. Thus, sediments can be investigated with respect to: the level of contamination, their toxicity, legislations that are changing and are amended, and possible methods of their management. The proposal of management of contaminated sediments is included in the Figure 1.

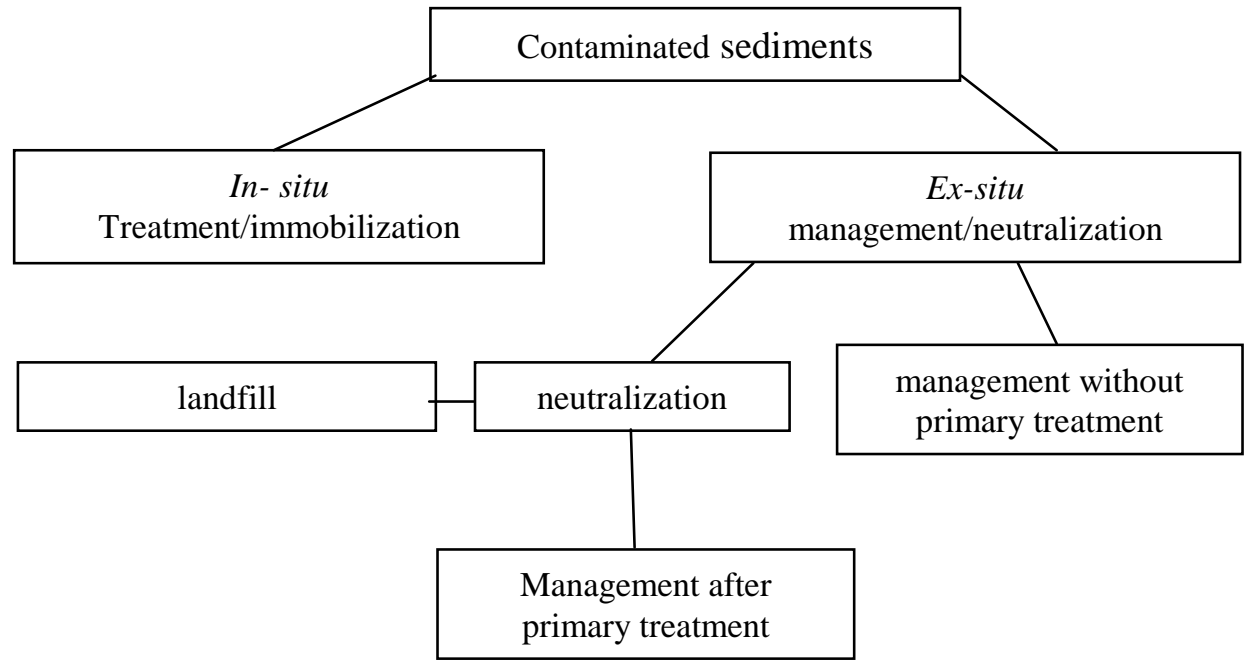

Fig 1. Proposal of sediment management

The results of investigations into POPs in Polish sediments indicate that high concentrations of these compounds were mainly observed in sediments with high loads of river pollutants coming from industrial plants. In the aforementioned plants rocks rich with organic matter undergo high temperature combustion processes. Another source of contamination originates from the rivers containing liquid fuels. Higher PAHs, PCBs and CP concentrations were found in the river sediments than in the lake sediments. Especially, sediments of the Oder River and its tributary, that is the most industrial part of Poland, were highly polluted. The origin of POPs in sediments is combined with municipal, industrial wastewater and surface run-off as well as a result of the sedimentation of solid particles from the air. The properties of sediments have 
an influence on PAHs concentration in sediments among which content of organic matter plays the most important role. Due to the low solubility, PAHs are absorbed to particulate matter and deposited in bottom sediments can be accumulated by various aquatic organisms that is of increasing environmental concern due to their mutagenic and carcinogenic properties. The available monitoring data indicate that although some of pesticide compounds are not currently apply the are still present in the sediments especially of their isomers and metabolites. In water and sediment samples from several sites, the DDT/DDE ratio was higher than 1, indicating fresh input of DDT in the studied area or inhibition of its breakdown. The wastewater treatment with respect to POPs should takes into consideration the application of less toxic plant protection agents. It is a new challenge to stop re-contamination of the water system from the secondary sources of pollution (e.g. sediments) and to achieve a gradual improvement of surface water quality. Therefore, there is a need to find the possible methods of clean-up polluted sediments.

Although the monitoring studies of sediments are conducted, up till now there are no still specific regulations concerning the scope and manner to measure and assess the state of water sediments in the case of rivers and lakes. Thus, it seems to be reasonable to standardize the ranges of analyses with respect to priority substances for the water environment.

Acknowledgement: This study was supported by BS-PB-402-301/11

\section{REFERENCES}

1. The state environment monitoring programme for the years 2016-2020, GIOŚ, Warsaw 2015 [in Polish] .

2. Report on the state of the rivers' and lakes' sediments contamination in 2009 year in Poland [in Polish] http://ekoinfonet.gios.gov.pl/

3. Report on the state of the rivers' and lakes' sediments contamination in 2010 year [in Polish] http://ekoinfonet.gios.gov.pl/

4. Report on the state of the rivers' and lakes' sediments contamination in 2011 year [in Polish] http://ekoinfonet.gios.gov.pl/

5. Report on the state of the rivers' and lakes' sediments contamination in 2012 year [in Polish] http://ekoinfonet.gios.gov.pl/

6. Environment Protection 2015, Central Statistical Office, Regional and Environmental Surveys Department, Warsaw 2015 [in Polish].

7. Bojakowska I., Sokołowska G.: Geochemical Classes of Cleaning Sediments, Prz. Geol., 46, 49-53 (1998). [in Polish] 
8. Dembska G., Grynkiewicz M., Wiśniewski, Aftanas S. B.: Physical and Chemical Investigations of the State of the Gdansk Dumping Ground as a Site for Disposing Sea-Area Dredged Spoils, Ochr. Pow. i Probl. Odpadów, 38, 10-19 (2004). [in Polish]

9. Malina G., Smit M., Grotenhuis T.: The Initial Risk Assessment and Emission Control from Contaminated Sediments, Ecohydrology\&Hydrobiology, 6, 213-218 (2006).

10. Korte N.A.: Guide for the Technical Evaluation of Environmental Data, Technomic Publishing Comp.Inc: Lancaster, USA (1999).

11. Włodarczyk-Makuła M.: Physical and chemical fates of organic micropollutants, Scholar-Press, Saarbrucken, Germany, ISBN 978-3-63985930-0 (2015).

12. Włodarczyk-Makuła M., Popenda A.: Quantative changes of PAHs in water and wastewater during Treatment Processes, in Wastewater treatment, Occurrence and fate of Polycyclic Aromatic Hydrocarbons (PAHs), CRC press, Taylor\&Francis Group, 47-70 (2015).

13. Janosz-Rajczyk M., Wiśniowska E., Włodarczyk-Makuła M., Popenda A.: PAHs in Organic Waste - Levels and Removal Possibilities in Pathways of Pollutants and Mitigation Strategies of their Impact on the Ecosystems, Komitet Inżynierii Środowiska PAN: Lublin, Poland (2004).

14. Grotenhuis T., Malina G., Satijn H.M.C, Smit M.P.J., Popenda A.: Surface Water as Receptor for Persistent Organic Pollutants and Heavy Metals, [In:]Proceedings of the $8^{\text {th }}$ International FZK/TNO Conference on Contaminated Soil, ConSoil, Gent, Belgium, May (2003).

15. Anitescu G., Tavlarides L.L.: Supercritical Extraction of Contaminants from Soils and Sediments, J. Supercrit. Fluids, 38, 167-180 (2006).

16. Tang N.H., Myers T.E.: PCB Removal from Contaminated Dredged Material, Chemosphere, 46, 477-484 (2002).

17. Evangelou V.P.: Environmental Soil and Water Chemistry, Principles and Applications, A Wiley-Interscience Publication: Toronto, Canada (1998).

18. Water Framework Directive 2006/60/EC

19. Regulation of the Minister of the Environment of 15 November 2011 concerning the forms and manner to monitor surface water and groundwater bodies is taken into consideration, 258, 1550 [in Polish].

20. Regulation of the Minister of the Environment of 10 November $2011 \mathrm{r}$. considering list of priority substances in the water politics [in Polish].

21. Water Framework Directive 2008/105/EC

22. Stockholm Convention on Persistent Organic Pollutants. United Nations Environment Programme 2001 (Dz.U.14.poz.76) 
23. Regarding Types and Concentrations of Substances Indicating that Dredging Spoil is Polluted, Dz. U. 02.55.498, Regulation of the Ministry of Environment: Warsaw, Poland 2002 [in Polish].

24. Regarding Standards of Quality of Soil, Dz. U. 02.165.1359, Regulation of the Ministry of Environment: Warsaw, Poland 2002 [in Polish].

25. Neilson A., Hynning P., PAHs, Products of Chemical and Biochemical Transformation of Alicyclic Precursors in PAHs and Related Compounds, Springer-Verlag: Berlin Heidelberg, Germany (1998).

26. Gąsecka M., Włodarczyk-Makuła M., Popenda A., Drzewiecka K.: Phytoremediation, Management of Environmental contaminants, Phytoremediation of PAH-contaminated areas, vol 1. Springer international publishing Switzerland, 9, 295-308 (2015).

27. Wild S.R., Jones K.C.: Polynuclear Aromatic Hydrocarbons in the United Kingdom Environment: a Preliminary Source Inventory and Budget, Environ. Pollution, 88, 91-108 (1995).

28. Harvey R.: Environmental chemistry of PAHs in PAHs and related compounds. Chemistry, Springer-Verlag: Berlin-Heidelberg, Germany (1998).

29. Wolska L., Namieśnik, J.: Distribution of Pollutants in the Oder River System. Pt.2: Organic Pollutants in Bottom Sediments, Pol. J. Environ. Studies, ,11, 663668 (2002).

30. Bojakowska I., Gliwicz T., Małecka K.: The Results of Geochemical Monitoring of Sediments in Poland in 2003-2005; IOS Library of Environmental Monitoring: Warsaw, Poland (2006). [in Polish]

31. Kostecki M., Czaplicka M., Węglarz A.: Selected Organic Compounds (BTEX, PAHs) in Sediments Anthropogenic Water Reservoir Dzierżno-Duże (Silesia Region), Arch. Ochr. Środ., 26, 95-108 (2000). [in Polish]

32. Kostecki M.: Alokacja $i$ przemiany wybranych zanieczyszczeń $w$ zbiornikach zaporowych hydrowęzła rzeki Kłodnicy i Kanale Gliwickim, Instytut Podstaw Inżynierii Środowiska PAN, Prace i Studia Zabrze, 57 (2003).

33. Tomza-Marciniak A., Witczak A.: Bioaccumulation of DDT and its metabolites in the Międzyodrze Ecosystem, Poland, Polish J. of Environ. Stud., 18, 3, 467-474 (2009).

34. Kaley K. B., Carlisle J., Siegel D., Salinas J.: Health Concerns and Environmental Issues with PVC-Containing Building Materials in Green Buildings, Integrated Waste Management Board, California Environmental Protection Agency, USA (2006). 
35. Bojakowska I., Gliwicz T.: Chlorinated Pesticides and Polychlorinated Biphenyls in River Sediments of Poland, Prz. Geol., 53, 649-655 (2005). [in Polish]

36. Kannan K., Maruya K., Tanabe S.: Distribution and Characterization of Polychlorinated Biphenyl Congeners in Soil and Sediments from a Superfund Site Contaminated with Arcolor 1268, Environ. Sci. Technol., 31, 1483-1488 (1997).

37. Bojakowska I., Sokołowska G., Gliwicz T.: POPs- PAHs, PCBs and CP in Sediments of Wtocławski Reservoir, Prz. Geol., 48, 837-843 (2000). [in Polish]

38. Mủeller A., Schilling P.: Sedimentbelastung und Stoffhaushalt im Nordlichen Peenestorm. In Schadstoffbelstung der sedimente in den Ostseekustengewassern. BfG: Koblenz-Berlin, Germany (1998).

39. Urbaniak M., Kiedrzyńska E., Zalewski M.: The role of a lowland reservoir In the transport of micropollutants, nutrients and the suspended particulate matter along the River continuum, Hydrology Research, 434, 400-411 (2012).

40. Stockholm Convention on Persistent Organic Pollutants. United Nations Environment Programme (2001).

41. Grynkiewicz M., Polkowska Z., Górecki T., Namieśnik J.: Pesticides in Precipitation from an Urban Region in Poland (Gdańsk-Sopot-Gdynia Tricity) between 1998 and 2000, Water, Air, Soil Pollut., 149, 3-16 (2003).

42. Ciesielczuk T., Kusza G., Karwaczyńska U.: Natural usage of bottom sediments on the base of existing law rules, Annual of Environmental Protection, 13, 1327-1337 (2011). [in Polish]

43. Brugmann L.: Hintergrundbelastung von Ostsee-Seidmentationsbecken vor der Deutschen Kuste. In Schadstoffbelstung der Sedimente in den Ostseekustengewassern. BfG: Koblenz-Berlin, Germany (1998).

\section{ZANIECZYSZCZENIE OSADÓW DENNYCH MIKROZANIECZYSZCZENIAMI ORGANICZNYMI: STAN AKTUALNY I PERSPEKTYWY}

\section{Streszczenie}

$\mathrm{W}$ pracy przedstawiono stan zanieczyszczenia osadów dennych w Polsce wybranymi zanieczyszczeniami organicznymi na podstawie danych monitoringowych oraz literatury. Scharakteryzowano osady rzeczne i jeziorne pod względem zawartości takich zanieczyszczeń organicznych jak: wielopierścieniowe węglowodory aromatyczne (WWA) polichlorowane bifenyle (PCBs) i chloroorganiczne pestycydy (CP) W 
nawiązaniu do przepisów prawnych. Przedstawiono źródła obecności zanieczyszczeń tymi związkami w osadach dennych. Na podstawie dostępnych danych stwierdzono, że osady rzeczne są w większym stopniu obciążone WWA, PCBs i CP w porównaniu do osadów jeziornych. Szczególnie zanieczyszczone okazały się osady pobierane z rzeki Odry i jej dopływów, w rejonach południowej części Polski. W celu minimalizacji ryzyka wtórnego zanieczyszczenia wód konieczne jest wprowadzenie jednolitego systemu zarządzania w zakresie postępowania osadami dennymi. Istotne jest także opracowanie aktów prawnych regulujących warunki gospodarowania osadami dennymi.

Słowa kluczowe: osady denne, WWA, PCB, chlorowane pestycydy, zanieczyszczenie.

Editor received the manuscript: 19.02 .2016 